\title{
CONTRIBUTION OF INTERSPECIFIC AND INTERGENERIC HYBRIDIZATION TO SUNFLOWER BREEDING
}

\author{
Christov, M.
}

Dobroudja Agricultural Institute, 9520 General Toshevo, Bulgaria

Received: November 02, 2012

Accepted: June 10, 2013

\section{SUMMARY}

This investigation was directed to sunflower improvement using hybrid forms resulted from wide hybridization. The aim was to create new B/A and $\mathrm{R}$ lines from interspecific and intergeneric hybrids resistant to diseases, parasite broomrape, herbicides, other stress factors and with high combining ability in highly productive oil-type sunflower hybrids with varied fatty acid contents. The confectionary hybrids should have a high kernel protein content and amino acid content.

The investigation was carried out during the period 1983-2010. The programme included 16 cultivars and $18 \mathrm{~B}$ lines with their analogues. Interspecific, intraspecific, and intergeneric hybridization produced hybrid materials originating from 38 Helianthus species with different ploidy levels, 9 annuals and 29 perennials, and 28 species from other genera of family Compositae. New sunflower forms and lines created possessed resistance to downy mildew, Phomopsis, Phoma and Alternaria, tolerance to Sclerotinia and total resistance to the different races of parasitic broomrape. The new forms had distinctive plant architecture, different vegetation periods, and seeds of different sizes and coloration. New B/A and R lines, characterized with high combining ability, seed oil, and fatty acid content and varying protein amino acid contents were obtained. Fifteen sources of cytoplasmic male sterility $(\mathrm{cms})$ were obtained from interspecific hybrids and 271 sources of fertility restoration $(R f)$ genes from interspecific and intergeneric hybrids. Five new oil type hybrids and one confectionery type were developed and registered.

The results from this investigations showed that by wide hybridization new genetic material can be transferred to the cultivated sunflower. These results supplemented the contribution of interspecific and intergeneric hybridization for sunflower breeding.

Key words: Compositae, Helianthus, hybridization, hybrids, lines, sunflower

\section{INTRODUCTION}

The practical implementation of interspecific hybridization began at the beginning of the $20^{\text {th }}$ century by Satziperov (1916). These and other later investigations showed that as a result of crossing of different Helianthus species with cultivated sunflower (Helianthus annuus L.), new sunflower forms resistant to different dis-

* Corresponding author: e-mail: misho_h5@abv.bg 
eases and the broomrape parasite could be obtained (Panchenko, 1954; Pustovoit V., 1960; Pustovoit G., 1963, 1975; Putt and Sackston, 1957, 1963; Leclercq et al., 1970; Hoes et al., 1973; Fick et al., 1974; Zimmer and Fick, 1974; Cvetkova, 1976; Škorić, 1985; Jan and Chandler, 1985; Christov, 1990a; Christov et al., 1996; Fernandez-Martinez and Ruso, 1997; Gulya et al., 1997; Bachvarova, 2004; Hristova-Cherbadzhi, 2007, 2012; Christov, 2008). Sunflower forms with higher seed oil content were obtained from crosses between different species and cultivated sunflower (Hristova-Cherbadzhi, 2007, 2012; Christov, 2008). Morized et al. (1984) and Iurras and Voinescu (1984) obtained drought tolerant forms from wild species $H$. argophyllus Torr. \& Gray. Leclercq $(1969,1971)$ found the first $\mathrm{cms}$ source originating from the cross between $\mathrm{H}$. petiolaris Nutt. and cultivated sunflower. Other cms sources were found by Anashchenko (1974), Whelan (1980, 1981), Heiser (1982), Vranceanu et al. (1986), Serieys and Vincourt (1987), Christov (1990b, 1999). Soon after discovery of the first cms source, sources of $R f$ genes were found by Kinman (1970) and Enns et al. (1970). Vranceanu and Stoenescu (1971, 1976,1978), Fick et al. (1974), Škorić et al. (1978), Serieys (1986), Škorić et al. (1987), Christov and Petrov (1988), and etc. followed in this direction.

Compared to interspecific hybridization, intergeneric hybridization has been rarely attempted. Crossing of Helianthus species with species from Tithonia and Viguera were some of the first attempts. Heiser et al. (1969) successfully crossed four Helianthus species with Viguiera porteri. Intergeneric hybridization between cultivated sunflower and the species Carthamus tinctoris L. and Onopordon acanthium L. was carried out by Morozov (1947). This indicated that the borders of sunflower crossability were vastly increased. Georgieva-Todorova $(1971,1976)$ carried out intergeneric hybridization between sunflower and species Onopordon acanthium L. indicating that some experiment plants were intergeneric hybrids. Unfortunately, did not explain exactly how they were obtained the intergeneric hybrids with sunflower. Our investigation in this field began in 1985. The first intergeneric hybrid was obtained in 1987 from cross between cultivated sunflower Helianthus annuus, variety Peredovik and Tithonia rotundifolia L., accession No. 567 (Christov and Panayotov, 1991). After obtaining positive results from the initial hybridization, additional genera from the Compositae family were used (Christov et al., 1994; Christov and Vassilevska-Ivanova, 1999; and Christov et al., 2009).

This report presents the results of interspecific and intergeneric sunflower hybrids and their use in obtaining hybrid material for developing lines with economically important characters suitable as parental lines for developing new sunflower hybrids.

\section{MATERIAL AND METHODS}

The investigations were carried out at the Dobroudja Agricultural Institute (DAI), General Toshevo, Bulgaria during the period 1983-2010.

\section{Plant material}

The investigation included 16 cultivars of cultivated sunflower Helianthus annuus $(2 \mathrm{n}=34)$ : Peredovik, Progress, Voronejskii 272, Skorospelii, Nadejdnii, Pervenets, Harkovski 101, Start, VNIIMK 8931, 6540, 1646, 3497, 8883, Vihren, Bal- 
kan, Stadion and 18 lines: No. 130, 1234, 1607, 1721, 2418, 2607, 2942, 3004, $6046,6054,6065,6075,6068,6633$, HA 89, HA 300, HA 341, HA 821 and their sterile analogues and hybrid material originated from 38 Helianthus species and 28 species from other genera of Compositae family.

\section{Methods used}

Methods of intraspecific hybridization and selection were used. They included crossing between interspecific hybrids, between intergeneric hybrids, and crossing of interspecific and intergeneric hybrids with sunflower cultivars and lines. Self-pollination, sib-pollination, backcrossing with pollen from cultivated sunflower and pollination with pollen from different interspecific and intergeneric hybrids were used.

Evaluation for resistance to diseases (Iliescu, 1955; Panchenko, 1965; Pustovoit et al., 1976; Saliman et al., 1982; Tourvieille et al., 1988; Christov, 1990a; Christov et al., 1992; Christov, 1996a, 1996b; Christov et al., 1996; Encheva and Kiryakov, 2002; Christov et al., 2004) and parasite broomrape (Panchenko, 1975; Alonso, 1996; Pacureanu-Joita et al., 1998; Fernandez-Martinez et al., 2000; Shindrova, 2006a, 2006b) was carried out using standardized methods used at the DAI.

Seed oil and protein contens and fatty and amino acid contents were also evaluated according to standardized methods (Rushkovskii, 1957; Stojanova and Ivanov, 1968; Ivanov et al., 1996). Nuclear Magnetic Resonance was used for evaluation of seed oil content and a Hitachi, L-8500 analyzer for amino acids.

Morphological characteristics were based on phenotypic observations and biometric measurements during the vegetation period and on laboratory studies of whole plants and seeds.

Sources of $\mathrm{cms}$ were searched for among the materials obtained from crosses of wild species $\times$ cultivated sunflower. Cytoplasmic male sterility was maintained by using pollen from B lines or cultivars. After sterility maintenance and confirmation of cytoplasmic type, comparative studies with other $\mathrm{cms}$ sources obtained at DAI, and others from all over the world were begun. Evaluation of the cytoplasmic effect on some agronomic characteristics of lines and hybrids included in some cms sources was also studied.

$\boldsymbol{R} \boldsymbol{f}$ genes were searched for in crosses of sterile sunflower lines $\times$ wild species. Presence of $R f$ genes in the genome of wild species was established in the $\mathrm{F}_{1}$. Lines with $R f$ genes were also found in materials obtained from crosses of cultivated sunflower / B line or cultivar / $\times$ wild species and wild species $\times$ cultivated sunflower. Confirmation was carried out when pollen of this material was used for pollination of sterile plants of cultivated $\mathrm{cms}$ sunflower sources. In all cases $R f$ genes were tested on several $\mathrm{cms}$ sources and the genetic determination of fertility restoration was studied.

Development of B lines was carried out by selection of hybrid materials, which in most cases began after the third generation and usually continued to the 9 through 12 generations. Evaluation and selection of materials was based the basis 
of morphological, biochemical and phytopathological characteristics, absence of $R f$ genes, and presence of good combining ability.

Development of sterile analogues, A lines, and B lines, began with establishment of the fact that there were no $R f$ genes in the material. After the $\mathrm{BC}_{3}$ or $\mathrm{BC}_{4}$, study of general combining ability of the A lines, and after that their specific combining ability for developing the best hybrid combinations began.

Creation of self-pollinated lines, restorers of fertility - $\mathrm{R}$ lines was carried out mainly from crosses of male sterile lines with different wild Helianthus species and species from other genera of the Compositae. Repeated selection and self-pollination of fertile plants was implemented until obtaining homozygous $R f$ genes. The $\mathrm{R}$ lines possessing $100 \%$ fertility restoration and other important characters were identified from both parental forms included in the hybridization (Christov, 2002; Christov et al., 1996, 2009). R lines obtained from crosses of cultivated sunflower / B line or cultivar/ $\times$ wild species and wild species $\times$ cultivated sunflower can be used to produce hybrids.

Hybrid combinations were created using sterile analogues, A lines, of B lines, obtained from interspecific hybridization and experimental mutagenesis, including several $\mathrm{cms}$ sources and $\mathrm{R}$ lines, obtained from interspecific and intergeneric hybridization. Different Bulgarian and foreign A lines were also used. The new hybrids, $\mathrm{A} \times \mathrm{R}$, were tested and the best were entered in competitive trials and recommended to be included in testing trials of State Variety Commission of Bulgaria and of similar authorized agencies of other countries.

\section{RESULTS AND DISCUSSION}

\section{Origin of interspecific hybrids}

As a result of hybridization between cultivated sunflower Helianthus annuus and 38 species from genus Helianthus, some $67000 \mathrm{~F}_{1}$ hybrid plants were obtained from all species combinations (Table 1 ). Only $F_{1}$ hybrids originating from H. simulans did not produce seeds.

Table 1: Species of genus Helianthus, used in hybridization

\begin{tabular}{|c|c|}
\hline Groups of species & Species \\
\hline $\begin{array}{l}\text { Annual species } \\
(2 n=34)\end{array}$ & $\begin{array}{l}H . \text { argophyllus, } H \text {. bolanderi, } H \text {. debilis, } H \text {. exilis, } H \text {. neglectus, } \\
H \text {. paradoxus, } H \text {. petiolaris, } H \text {. praecox, and } H \text {. annuus (wild)** }\end{array}$ \\
\hline $\begin{array}{l}\text { Perennial diploid species } \\
(2 n=34)\end{array}$ & $\begin{array}{l}\text { H. divaricatus, } H . \text { doronicoides }{ }^{\star}, H \text {. giganteus, } H \text {. smithii, } \\
\text { H. glaucophyllus, } H \text {. grosseserratus, } H \text {. maximiliani, } \\
H . \text { microcephallus, } H \text {. mollis, } H \text {. nuttallii, } H \text {. occidentalis, } \\
\text { H. orgialis*, } H \text {. pumilus, } H \text {. salicifolius, } H \text {. silphioides, and } H \text {. simulans }\end{array}$ \\
\hline $\begin{array}{l}\text { Perennial tetraploid species } \\
(2 n=68)\end{array}$ & $\begin{array}{l}H . \text { decapetalus, } H \text {. hirsutus, } H \text {. laevigatus, } H \text {. scaberimus*, } \\
\text { and } H \text {. tomentosus* }\end{array}$ \\
\hline $\begin{array}{l}\text { Perennial hexaploid species } \\
(2 n=102)\end{array}$ & $\begin{array}{l}H . \text { eggertii, } H . \text { pauciflorus (rigidus), } H . \text { strumosus, } H . \text { resinosus, } \\
H \text {. tuberosus, } H \text {. ciliaris, } H . x \text { laetiflorus, and } H \text {. californicus }\end{array}$ \\
\hline
\end{tabular}

*Not included in classification of Schilling and Heiser (1981); **Wild form. 
Hybrid plants from the different combinations produced great phenotypic diversity. Some combined useful characters of the parental forms. The diversity provided an opportunity to select for a large number of characters. Selection directed toward valuable characters and self-pollination lead to uniformity in plants in the next generations.

Genes controlling resistance to diseases, parasites and other stress factors were discovered in many of the hybrids. Plants with a new architecture, different vegetation period, and different coloration of seeds were obtained. Many of the new forms had high combining ability and high seed oil content; higher than that of cultivated sunflower. A large number of new $\mathrm{cms}$ sources and genes for fertility restoration $(R f)$ were obtained (Table 2 ).

Table 2: Sources of new characters transferred into cultivated sunflower

\begin{tabular}{|c|c|}
\hline Characters & Snpoing \\
\hline Resistance/tolerance to: & Species \\
\hline Plasmopara helianthi & $\begin{array}{l}\text { H. annuus (wild), } H \text {. argophyllus, } H \text {. bolanderi, } H \text {. debilis, } H \text {. exilis, } H \text {. } \\
\text { neglectus, } H \text {. paradoxus, } H \text {. petiolaris, } H \text {. praecox, } H \text {. divaricatus, } H \text {. } \\
\text { doronicoides, } H \text {. giganteus, } H \text {. glaucophyllus, } H \text {. grosseserratus, } H \text {. } \\
\text { mollis, } H . \text { maximiliani, } H \text {. microcephalus, } H \text {. nuttallii, } H \text {. occidentalis, } \\
\text { H. orgialis, } H \text {. pumilus, } H \text {. salicifolius, } H \text {. smithii, } H \text {. decapetalus, } H \text {. } \\
\text { hirsutus, } H \text {. laevigatus, } H \text {. scaberimus, } H \text {. tomentosus, } H \text {. eggertii, } H \text {. } \\
\text { californicus, } H \text {. ciliaris, } H \text {. pauciflorus, } H \text {. resinosus, } H \text { strumosus, } H \text {. } \\
\text { tuberosus, and } H \text { laetus }\end{array}$ \\
\hline Phomopsis helianthi & $\begin{array}{l}\text { H. annuus (wild), H.argophyllus, H. debilis, H. eggertii, H. pauciflorus, } \\
\text { H. glaucophyllus, and H. laevigatus }\end{array}$ \\
\hline Erysiphe cichoracearum & H. decapetalus, H. laevigatus, $H$. glaucophyllus, and $H$. ciliaris \\
\hline Orobanche cumana & $\begin{array}{l}\text { H. tuberosus, H. eggertii, H. smithii, H. argophyllus, H. pauciflorus, H. } \\
\text { strumosus, and H. debilis }\end{array}$ \\
\hline Phoma helianthi & $H$. argophyllus, $H$. laevigatus, $H$. eggertii, and $H$. debilis \\
\hline Sclerotinia sclerotiorum & $\begin{array}{l}\text { H. praecox, H. argophyllus, } H \text {. annuus (wild), H. petiolaris, H. eggertii, } \\
\text { H. pauciflorus, and } H \text {. smithii }\end{array}$ \\
\hline Earliness & $\begin{array}{l}\text { H. praecox, H. scaberimus, H. glaucophyllus, } H \text {. giganteus, } H \text {. pauci- } \\
\text { florus (rigidus), } H \text {. nuttallii, } H \text {. ciliaris, and } H \text {. annuus (wild) }\end{array}$ \\
\hline Seed size & $H$. annuus (wild), $H$. argophyllus, $H$. tuberosus and $H$. strumosus \\
\hline High oil content & $\begin{array}{l}\text { H. annuus (wild), H. debilis, H. petiolaris, H. praecox, H. pauciflorus, } \\
\text { and } H . x \text { laetiflorus }\end{array}$ \\
\hline Genes, controlling $\mathrm{cms}$ & $\begin{array}{l}\text { H. annuus (wild), H. argophyllus, H. debilis, H. petiolaris, H. praecox, } \\
\text { H. pauciflorus, and H. strumosus }\end{array}$ \\
\hline Rf genes & 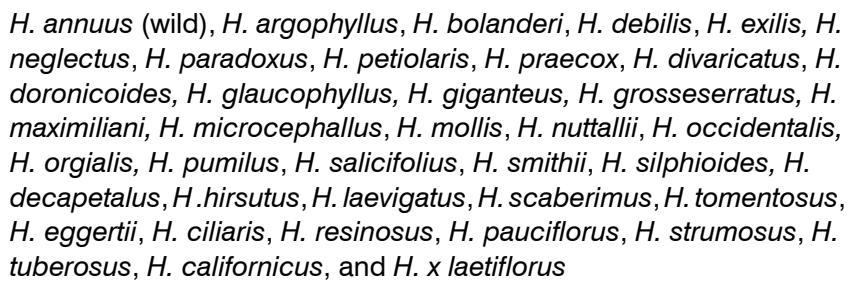 \\
\hline
\end{tabular}




\section{Origin of intergeneric hybrids}

A total of $805 \mathrm{~F}_{1}$ hybrid plants were obtained from direct crosses and $19 \mathrm{~F}_{1}$ hybrid plants from reciprocal crosses originating from sunflower and 28 species from other genera of the Compositae (Table 3). Second generation hybrid plants were obtained from the combination $H$. annuus $\times$ Simsia foetida, and from all 19 $\mathrm{F}_{1}$ hybrid plants from the reciprocal crosses. Only those from the combination Tithonia speciosa $\times H$. annuus reached the sixth generation.

Despite $R f$ genes, some other characters with economic importance were transferred. Resistance to downy mildew, Phomopsis, Sclerotinia, Alternaria, and broomrape were obtained. Other forms were identified with smaller stems and shorter vegetation periods. Some forms had higher seed oil content, while others had variation in amino acids and protein contents. Table 4 shows the species from which these characters were transferred from.

\section{Creating of new sunflower forms from interspecific and intergeneric hybrids}

The scheme for creating of new sunflower forms and lines from the interspecific and intergeneric hybrids was similar. The difference between them was that the hybrid material mainly originated from the intergeneric hybridization in this case where the forms and lines carry $R f$ genes.

The main reason for including wild Helianthus species and some other species from the Compositae in the research was the presence of resistance to diseases, parasites, and pests. The artificial testing of the new hybrids, obtained as a result of wide hybridization, to diseases began in different generations and depended on the quantity of seeds obtained and the phenotype of the plants. In most cases, $F_{1}$ plants were tested if there was sufficient seed. Sufficient number of plants was obtained mainly from crosses with annuals and from crosses using $\mathrm{cms}$ lines $\times$ Helianthus species or another genus of the Compositae. Studies for downy mildew resistance were a priority followed by studies for Sclerotinia, Phomopsis, Phoma, and Alternaria resistance. A high priority was also given to evaluating broomrape resistance.

Breeding to develop high oil hybrids from the interspecific and intergeneric hybrids was based on some important characters such as high ratio kernel/hull and increasing the oil content in the kernel. The next priority related to the high seed productivity and seed oil content was 1000 seeds weight, which depends on the ratio of percent kernel/percent seed and percent oil content in the kernel. Another important index was number of seeds obtained per plant which had intermediate inheritance and a positive relationship between the number of seeds per plant and its productivity.

Other characters important for sunflower breeding were: seed size and hull coloration; friability of seeds; percent seed set; plant height; head diameter; vegetation period; branching, lodging; number of leaves per plants lines; hybrid cultivars; and number of plants/unit area. 
Table 3: Species from different genera of the Compositae used in hybridization with cultivated sunflower

\begin{tabular}{|c|c|}
\hline Groups of species & Species from the Compositae \\
\hline $\begin{array}{l}\text { Species with the same } \\
\text { chromosome number as } \\
\text { sunflower }(2 n=34)\end{array}$ & $\begin{array}{l}\text { Gaillardia speciosa, Onopordum acanthium, Simsia foetida, Titho- } \\
\text { nia rotundifolia, Tithonia speciosa, Verbesina alata, V. helian- } \\
\text { thoides, V. encelioides, and Viguera trachyphylla }\end{array}$ \\
\hline $\begin{array}{l}\text { Species with a different } \\
\text { chromosome number } \\
(2 n=x x)\end{array}$ & $\begin{array}{l}\text { Arctium lapa }(2 n=32) \text {, Aster speciosa }(2 n=72) \text {, Bidens tripartita } \\
(2 n=48) \text {, Calendula officinalis }(2 n=28) \text {, Carduus acanthoides } \\
(2 n=22) \text {, Carthamus lanatus }{ }^{*}(2 n=44) \text {, Carthamus tinctorius } \\
(2 n=24) \text {, Carlina vulgaris }(2 n=20) \text {, Chrysanthemum leucanthe- } \\
\text { mum }{ }^{\star}(2 n=18) \text {, Cichorium intybus }(2 n=18) \text {, Cirsium lanceolatum* } \\
(2 n=68) \text {, Cosmos bippinatus }(2 n=24) \text {, Grindelia speciosa } \\
(2 n=24) \text {, Ehinacea purpurea }(2 n=22) \text {, Evmolpia sp. }(2 n=?) \text {, Inula } \\
\text { helenium }(2 n=20) \text {, Matricaria chamomila }(2 n=18), \text { Rudbeckia hir- } \\
\text { ta* }(2 n=36) \text {, Silphium perfoliatum }(2 n=24) \text {, Silybium marianum, } \\
\text { Telekia speciosa }(2 n=20) \text {, Tithonia tagetiflora }(2 n=32) \text {, Zinnia an- } \\
\text { gustifolia }(2 n=22) \text {, and Xanthium strumarium }(2 n=36)\end{array}$ \\
\hline
\end{tabular}

*Species from which intergeneric hybrids were not obtained.

Table 4: Sources of new characters transferred to cultivated sunflower

\begin{tabular}{|c|c|}
\hline Characters & Snecies \\
\hline Resistance/tolerance to: & \\
\hline Plasmopara helianthi & $\begin{array}{l}\text { Race } 731 \text { - Inula helenium, Tithonia rotundifolia, } \\
\text { and Grindelia speciosa }\end{array}$ \\
\hline Phomopsis helianthi & Arctium lapa, and Carduus acanthoides \\
\hline Erysiphe cichoracearum & $\begin{array}{l}\text { V. encelioides, Grindelia speciosa, Ehinacea purpurea, } \\
\text { Tithonia rotundifolia, and Telekia speciosa }\end{array}$ \\
\hline Orobanche cumana & $\begin{array}{l}\text { Calendula officinalis, Carduus acanthoides, Grindelia speciosa, } \\
\text { Inula helenium, Tithonia rotundifolia, Tithonia speciosa, } \\
\text { and V. helianthoides }\end{array}$ \\
\hline Phoma helianthi & Arctium lapa, Grindelia speciosa, and V. encelioides \\
\hline Sclerotinia sclerotiorum & $\begin{array}{l}\text { Tithonia rotundifolia, Arctium lapa, Carduus acanthoides, Grindelia } \\
\text { speciosa, Inula helenium. Matricaria chamomile, Silphium perfolia- } \\
\text { tum, Telekia speciosa, and Zinnia angustifolia }\end{array}$ \\
\hline Earliness & Aster speciosa, Verbesina alata, and Telekia speciosa \\
\hline Seed size & Carduus acanthoides, Aster speciosa, and Carlina vulgaris \\
\hline High oil content & Carduus acanthoides, Gaillardia speciosa, and Grindelia speciosa \\
\hline $\begin{array}{l}\text { Various amino acid } \\
\text { protein content }\end{array}$ & $\begin{array}{l}\text { Carduus acanthoides, Bidens tripartite, Arctium lapa, } \\
\text { Grindelia speciosa, and V. helianthoides }\end{array}$ \\
\hline Rf genes & $\begin{array}{l}\text { Gaillardia speciosa, Onopordum acanthium, Tithonia rotundifolia, } \\
\text { Tithonia speciosa Verbesina alata, V. helianthoides, V. encelioides, } \\
\text { Viguera trachyphylla, Arctium lapa, Aster speciosa, Calendula offici- } \\
\text { nalis, Carduus acanthoides, Carthamus tinctorius, Carlina vulgaris, } \\
\text { Cichorium intybus, Cosmos bippinatus, Grindelia speciosa, Ehinacea } \\
\text { purpurea, Evmolpia sp., Inula helenium, Matricaria chamomila, Sil- } \\
\text { phium perfoliatum, Silybium marianum, Telekia speciosa, Tithonia } \\
\text { tagetiflora, Zinnia angustifolia, and Xanthium strumarium }\end{array}$ \\
\hline
\end{tabular}


Another direction of the breeding work was to increase the protein content of large seeded forms seeds suitable for human consumption, confectionery type with diverse amino acids and protein contents, and small colored seeds suitable for bird feeding.

Utilizing wide hybridization provides an opportunity to find new sources of $\mathrm{cms}$ and different sources of fertility restoration gens for the cms PET 1 and other cms sources, obtained at DAI and other research institutions.

\section{New sunflower resistance/tolerance to diseases and parasites}

Among the hybrids developed, resistance genes for downy mildew were the most frequent. Complete resistance to downy mildew races 300, 330 and 700 was observed in more than 2600 combinations obtained from crosses of 36 Helianthus species and 16 species from other genera of the Compositae (Tables 1 and 2). Resistance to races 731, considered as the most virulent in Bulgaria, was found in more than 400 hybrid forms, originating from the $H$. divaricatus, $H$. hirsutus, $H$. pauciflorus (rigidus), $H$. debilis ssp. debilis, $H$. paradoxus, Inula helenium, Tithonia rotundifolia, and Grindelia speciosa. More than 96\% of the resistant forms possessed $R f$ genes. Many of them are finished $\mathrm{R}$ lines. Some of these materials possess resistance to other diseases and to the parasite broomrape (Table 5). A group of materials resistant to the most virulent race was selected. The present work was connected to transfer of this resistance into $\mathrm{R}$ lines with other interesting characters obtained before the appearance of the newest races.

Table 5: Characterization of sunflower lines obtained by interspecific and intergeneric hybridization resistant to downy mildew race 731 harvested in 2009

\begin{tabular}{lcccc}
\hline \multirow{2}{*}{ Accession, pedigree } & \multicolumn{2}{c}{ Resistance to, \% } & \multirow{2}{*}{ Seed oil content, \% } & Generation \\
\cline { 2 - 5 } & downy mildew & broomrape & & 23 \\
PR-1/8 /c.s. $\times$ H. pauciflorus/ & 100 & 100 & 48.48 & 25 \\
PR-9/8 /c.s. $\times$ H. tuberosus/ & 100 & 100 & 47.27 & 16 \\
PR-13/8 /c.s. $\times$ H. pumilus/ & 100 & - & 58.28 & 25 \\
PR-25/8 /c.s. $\times$ H. pauciflorus/ & 100 & 100 & 46.89 & 16 \\
PR-35/8 /c.s. $\times$ H. hirsutus/ & 100 & 100 & 48.80 & 18 \\
PR-41/8 /c.s. $\times$ H. divaricatus/ & 100 & 100 & 47.03 & 18 \\
PR-51/8 /c.s. $\times$ C. acanthoides/ & 100 & - & 52.96 & $17^{*}$ \\
PR-56/8 /c.s. $\times$ Aster speciosa/ & 100 & 100 & 49.56 & 16 \\
PR-57/8 /c.s. $\times$ Inula/ Tith. & 100 & 100 & 50.35 & \\
\hline * & & & & \\
\hline
\end{tabular}

*unbranched form

Resistance/tolerance to Phomopsis helianthi was observed in more than 80 forms. They originated from species $H$. annuus (wild), $H$. argophyllus, $H$. debilis, H. glaucophyllus, H. laevigatus, H. eggertii, H. pauciflorus, Arctium lapa, and Carduus acanthoides (Table 6).

High resistance to Phoma helianthi was observed in several interspecific hybrids with $H$. eggertii, $H$. laevigatus, $H$. argophyllus, and $H$. debilis. 
Table 6: Characterization of sunflower lines obtained by interspecific and intergeneric hybridization for resistance to Phomopsis, Phoma, Alternaria, and Sclerotinia harvested in 2009

\begin{tabular}{lcccc}
\hline & \multicolumn{3}{c}{ Resistance to (grades) } \\
\cline { 2 - 4 } Accession, pedigree & $\begin{array}{c}\text { Phomopsis, } \\
\text { gr. 0-4 }\end{array}$ & $\begin{array}{c}\text { Phoma, } \\
\text { gr. 0-4 }\end{array}$ & $\begin{array}{c}\text { Alternaria, } \\
\text { gr. 0-4 }\end{array}$ & $\begin{array}{c}\text { Sclerotinia, } \\
\text { gr. 0-5 }\end{array}$ \\
\hline Sc-1 /c.s. $\times$ C. acanth./ & 3 & 0 & 0 & 1 \\
Sc-2 L-6116B & 1 & 0 & 0 & 2 \\
Sc-3 /c.s. $\times$ H. debilis/ & 0 & 0 & 1 & 2 \\
Sc-5 /c.s. $\times$ H.pauciflor/ & 2 & 0 & 3 & 0 \\
Sc-8 /c.s. $\times$ H. argophyllus/ & 0 & 0 & 0 & 0 \\
Sc-9 /c.s. $\times$ H. argophyllus/ & 0 & 0 & 0 & 1 \\
Sc-16 /c.s. $\times$ Silfium sp./ & 3 & 0 & 0 & 1 \\
Sc-18 /c.s. $\times$ Grindelia sp./ & 3 & 0 & 2 & 1 \\
Sc-23 /c.s. $\times$ Telekia sp./ & 2 & 0 & 1 & 0 \\
Sc-27 /c.s. $\times$ Inula sp./ & 1 & 0 & 0 & 0 \\
Sc-31 /c.s. $\times$ Gaillardia sp./ & 3 & 0 & 3 & 1 \\
Sc-33 /c.s. $\times$ Carduus sp./ & 0 & 0 & 2 & 1 \\
Sc-39 /c.s. $\times$ Inula sp./ $\times$ Tith. & 2 & 0 & 0 & 1 \\
Sc-51 /c.s. $\times$ Carduus sp./ & 1 & 0 & 2 & 1 \\
Sc-53 /c.s. $\times$ Tith. sp./ $\times$ Arct. & 1 & 0 & 3 & 1 \\
Sc-56 /c.s. $\times$ Arctium sp./ & 2 & 1 & 0 & 1 \\
Sc-60 /c.s $\times$ Tith. sp./ $\times$ Verbes. & 2 & 0 & 2 & 1 \\
Sc-62 /c.s $\times$ Grindelia sp./ & 1 & 0 & 0 & 1 \\
Sc-62 /c.s. $\times$ Zinnia sp./ & 0 & & 1 \\
\hline
\end{tabular}

Studies on Sclerotinia resistance (Sclerotinia sclerotiorum) were carried out under field conditions and in greenhouses. Different methods of artificial inoculation were used with the most effective with direct mycelium setting in different uncovered parts of the plant. The evaluation was based on a 0 to 5 scale (Encheva and Kiryakov, 2002; Christov et al., 2004). High tolerance to Sclerotinia sclerotiorum was observed on some crosses originating from Helianthus species, H. eggertii, $H$. pauciflorus, $H$. smithii, $H$. praecox, $H$. petiolaris, $H$. argophyllus, $H$. annuus (wild) and species from other genera, Tithonia rotundifolia, Arctium lapa, Carduus acanthoides, Grindelia speciosa, Inula helenium, Matricaria chamomile, Silphium perfoliatum, Telekia speciosa, and Zinnia angustifolia. Tolerance to the three forms of this pathogen that infects the head, stem, and the basal part of the sunflower stem was observed.

Total resistance to powdery mildew (Erysiphe cichoracearum) was found in hybrid forms originating from $H$. decapetalus, $H$. glaucophyllus, $H$. giganteus, $H$. mollis, $H$. ciliaris, $H$. laevigatus, $H$. debilis, $H$. tuberosus, and $H$. resinosus. The resistance transferred from the $H$. decapetalus was determined to be a single dominant gene. 
The investigations on Alternaria resistance (Alternaria helianthi) was began later. The more detail study of wild species was done during the period 1985-1989. At that time, the first crosses for creating hybrid forms with resistance to Alternaria were carried out. After that, only hybrid forms were tested. During the last years the method of Encheva and Kiryakov (2002) was used. Some of the results are presented in Table 6.

Races E, F and G of parasitic broomrape (Orobanche cumana) have spread in Bulgaria. The last two races appeared one after another and have complicated the sunflower breeding process. During the last 20 years a sufficient number of sunflower lines had broomrape resistance to race $\mathrm{E}$, the common race. However, since 2004 the aim of the breeding program was directed towards developing lines resistant to race $\mathrm{F}$ and since 2008 to race $\mathrm{G}$.

Seventeen wild Helianthus species were used (H. tuberosus, $H$. pauciflorus, $H$. eggertii, $H$. x laetiflorus, $H$. decapetalus, $H$. hirsutus, $H$. divaricatus, $H$. giganteus, $H$. maximiliani, $H$. nuttallii ssp. rydbergii, $H$. salicifolius, $H$. smithii, $H$. annuus (wild), $H$. argophyllus, $H$. debilis, $H$. petiolaris and $H$. praecox) and 5 species from genera Calendula, Carduus, Grindelia, Inula and Tithonia of family Compositae to obtain resistance to broomrape. Total resistance to this parasite have been developed in some lines such as 7019 R, 7203 R, C 23/1, C 41, C 46, C 48, C 55, and C 56. Table 7 shows the new developed lines.

Table 7: Characterization of sunflower lines obtained by interspecific and intergeneric hybridization and resistant to broomrape harvest in 2009

\begin{tabular}{|c|c|c|c|c|}
\hline \multirow{2}{*}{ Accession, pedigree } & \multicolumn{2}{|c|}{ Resistance to (\%) } & \multirow{2}{*}{ Seed oil content, \% } & \multirow{2}{*}{ Generation } \\
\hline & broomrape & downy mildew & & \\
\hline PR-1/8/c.s. $\times$ H. pauciflorus/ & 100 & 100 & 48.48 & 23 \\
\hline PR-9/8 /c.s. $\times$ H. tuberosus/ & 100 & 100 & 47.27 & 25 \\
\hline PR-19/8 /c.s. $\times$ H. divaricatus/ & 100 & 100 & 45.25 & 19 \\
\hline PR-25/8 /c.s $\times$ H. pauciflorus/ & 100 & 100 & 46.89 & 25 \\
\hline PR-35/8 /c.s $\times$ H. hirsutus/ & 100 & 100 & 48.80 & 16 \\
\hline PR-41/8 /c.s. $\times$ H. divaricatus/ & 100 & 100 & 47.03 & 18 \\
\hline PR-47/8 /c.s. $\times$ H. bolanderi/ & 100 & 100 & 50.44 & 19 \\
\hline PR-56/8 /c.s $\times$ Aster speciosa/ & 100 & 100 & 49.56 & 17 \\
\hline PR-57/8 /c.s. $\times$ Inula/ $\times$ Tith. & 100 & 100 & 50.35 & 16 \\
\hline PR-61/8 /c.s. × Aster speciosa/ & 100 & 100 & 51.41 & 17 \\
\hline PR-63/8 /c.s. $\times$ H. pauciflorus/ & 100 & 100 & 48.80 & 25 \\
\hline PR-68/8 /c.s × Tithonia/ × Verb. & 100 & 100 & 48.36 & 16 \\
\hline
\end{tabular}

\section{Resistance to imidazolinone herbicide}

Three sources for resistance to the herbicide Pulsar were used. About $80 \%$ of the obtained materials were $\mathrm{R}$ lines. The most advanced generations were lines obtained from the source for herbicide resistance from the USA (J. Miller) transferred into our materials using HA 425, HAR 426, and HAR 427. The best line was C 41. The lines based of the source BASF - BTI-M1 and BTI-R1 and our source (An 17) were obtained. 
Table 8: Amino acid content of seed protein of species' accession from the family Compositae, $\mathrm{g} / 100 \mathrm{~g}$ protein

\begin{tabular}{lcccccc}
\hline \multirow{2}{*}{ Species / Origin } & Protein & Lysine & Threonine & Cysteine & Valine & Methionine \\
\cline { 2 - 7 } & $\%$ & $\%$ & $\%$ & $\%$ & $\%$ & $\%$ \\
\hline Arctium lapa & 45.32 & 5.14 & 3.61 & 1.10 & 4.54 & 0.91 \\
Bidens tripartita & 47.50 & 5.82 & 3.67 & 1.03 & 4.80 & 1.56 \\
Cirsium lanceolatum & 44.06 & 4.92 & 3.46 & 1.31 & 4.50 & 1.03 \\
Onopordum acanthium & - & 4.42 & 3.70 & 1.04 & 4.71 & 1.54 \\
Tithonia rotundifolia & 64.11 & 3.60 & 3.73 & 1.45 & 4.31 & 1.52 \\
Tithonia speciosa & 66.82 & 3.73 & 3.82 & 1.36 & 4.35 & 1.78 \\
Viguera sp. & 60.68 & 3.50 & 3.10 & 1.69 & 4.05 & 1.77 \\
Verbesina alata & 78.74 & 3.73 & 2.96 & 1.60 & 4.10 & 1.27 \\
V. helianthoides & 79.82 & 3.51 & 2.95 & 1.29 & 4.11 & 1.51 \\
V. encelioides & 60.86 & 4.12 & 3.42 & 1.56 & 4.46 & 1.66 \\
Gaillardia hibrida & - & 3.50 & 3.10 & 1.69 & 4.05 & 1.77 \\
H. annuus - h. Albena & - & 3.41 & 4.63 & 0.63 & 4.73 & 2.1 \\
\hline
\end{tabular}

Table 9: Amino acid content of seed protein of 11 lines $\left(\mathrm{F}_{5}\right)$, originating from the cross $H$. annuus $\mathrm{x}$ Carduus acanthoides, g / 100 g protein

\begin{tabular}{|c|c|c|c|c|c|c|}
\hline \multirow{2}{*}{ No. } & \multirow{2}{*}{ Form / Sample } & \multirow{2}{*}{$\begin{array}{c}\text { Lysine } \\
\%\end{array}$} & \multirow{2}{*}{$\begin{array}{c}\text { Threonine } \\
\%\end{array}$} & \multirow{2}{*}{$\begin{array}{c}\text { Cysteine } \\
\%\end{array}$} & \multirow{2}{*}{$\begin{array}{c}\text { Valine } \\
\%\end{array}$} & \multirow{2}{*}{$\begin{array}{c}\text { Methionine } \\
\%\end{array}$} \\
\hline & & & & & & \\
\hline 1 & 1493/1-p & 3.58 & 4.47 & - & 5.37 & 0.29 \\
\hline 2 & $1494 / 1$ & 3.35 & 4.29 & 0.25 & 5.60 & 0.27 \\
\hline 3 & $1495 / 1$ & 3.16 & 4.16 & 0.22 & 5.49 & 0.47 \\
\hline 4 & 1496/1-p & 3.88 & 4.69 & 0.21 & 5.40 & 0.37 \\
\hline 5 & $1500 / 1$ & 3.25 & 4.24 & 0.23 & 5.52 & 0.39 \\
\hline 6 & $1500 / 2$ & 3.19 & 4.25 & 0.21 & 5.36 & 0.43 \\
\hline 7 & 1503/1-p & 4.11 & 4.86 & 0.31 & 5.73 & 0.63 \\
\hline 8 & 1504/1-p & 4.07 & 4.84 & 0.46 & 5.86 & 1.01 \\
\hline 9 & $1508 / 1-p$ & 3.38 & 4.38 & 0.23 & 5.46 & 0.54 \\
\hline 10 & $1511 / 1$ & 3.01 & 4.11 & 0.20 & 5.42 & 0.51 \\
\hline 11 & $1511 / 2$ & 3.16 & 4.30 & 0.30 & 5.38 & 0.63 \\
\hline 12 & C. acanthoides & 5.06 & 4.81 & - & - & - \\
\hline 13 & H. annuus - h. Albena & 3.41 & 4.63 & 0.63 & 4.73 & 2.1 \\
\hline
\end{tabular}




\section{New sunflower forms with high seed oil content}

Some accessions of wild Helianthus species could be used as sources for high seed oil content. This conclusion is based on results obtained by interspecific hybridization. Sunflower forms and lines with high seed oil content were obtained from hybrids with $H$. eggertii, $H$. pauciflorus (rigidus), $H$. smithii, $H$. hirsutus, $H$. annuus (wild), $H$. nuttallii ssp. rydbergii, and $H$ pumilus. From intergeneric hybridization we obtained forms with high seed oil content originating from species Carduus acanthoides, Gaillardia speciosa, Grindelia speciosa, and Telekia speciosa. Results for seed oil content are presented in Tables 5, 7 and 11 .

\section{New forms with high protein content in the seeds and rich diversity of amino acids}

Some Helianthus species and some other species from the Compositae were sources of high seed protein content and higher amino acid contents for humans and animals. Amino acid content of seed protein of some species from the family Compositae was higher of that in cultivated sunflower (Table 8). From valuation of the new hybrid forms was established that some of them were with higher amino acid contents, too (Tables 9 and 10).

\section{New sources of cms}

The total number of the new cms sources was 15 (Table 11). Some of the sources are different from $\mathrm{cms}$ PET 1. Fertility restoration genes were found for all cms sources.

\section{Sources of new Restorer fertility (Rf) genes}

The investigation was directed towards discovery of $R f$ genes for the common cms PET1 from $H$. petiolaris and for new $\mathrm{cms}$ sources discovered at DAI. In total, 271 crosses with 37 Helianthus species and some other species from the Compositae were found to carry $R f$ genes for $\mathrm{cms}$ PET 1. Rf genes were also found in Helianthus argophyllus, $H$. debilis and Helianthus rigidus (pauciflorus) for cms RIG-1, and $R f$ genes in Carduus acanthoides for cms ARG-3-M-1.

\section{New sunflower forms with $R f$ genes ( $R$ lines)}

The current research has obtained more than 3900 new $\mathrm{R}$ forms, including $1306 \mathrm{R}$ lines that have been fixed and named. All of them are resistant to downy mildew. Some are resistant to Phomopsis and broomrape. There were lines that showed resistance to Phoma and tolerance to Sclerotinia. All lines showed high combining ability. A partial list of these lines is presented in Table 12 . 
Table 10: Amino acid content of seed protein of 12 lines $\left(\mathrm{F}_{5}\right)$ originating from the cross H.annuus $\times$ Bidens tripartita, $\mathrm{g} / 100$ g protein

\begin{tabular}{llccccc}
\hline \multirow{2}{*}{ No. } & Form / Sample & Lysine & Threonine & Cysteine & Valine & Methionine \\
\cline { 2 - 6 } & & $\%$ & $\%$ & $\%$ & $\%$ & $\%$ \\
\hline 1 & $1515 / 1-p$ & 4.08 & 4.61 & - & 6.23 & 0.37 \\
2 & $1515 / 2-p$ & 3.51 & 4.26 & - & 6.16 & 0.44 \\
3 & $1516 / 1-p$ & 3.81 & 4.31 & - & 6.40 & 0.39 \\
4 & $1517 / 1$ & 3.18 & 4.17 & - & 6.30 & 0.29 \\
5 & $1518 / 1$ & 3.47 & 4.57 & 0.21 & 5.31 & 0.46 \\
6 & $1519 / 1$ & 3.10 & 4.13 & 0.23 & 5.30 & 1.06 \\
7 & $1520 / 1$ & 3.58 & 4.66 & 0.37 & 5.24 & 0.75 \\
8 & $1520 / 2$ & 3.18 & 4.30 & 0.26 & 5.15 & 0.67 \\
9 & $1526 / 1$ & 3.37 & 4.19 & 0.31 & 5.36 & 0.77 \\
10 & $1530 / 1$ & 3.61 & 4.47 & - & 5.57 & 0.44 \\
11 & $1574 / 1$ & 3.15 & 4.23 & 0.70 & 4.72 & 0.57 \\
12 & $1574 / 2$ & 3.30 & 4.32 & 0.24 & 4.88 & 0.22 \\
13 & Bidens tripartita & 5.82 & 3.67 & 1.03 & 4.80 & 1.56 \\
14 & H. annuus - h. Albena & 3.41 & 4.63 & 0.63 & 4.73 & 2.1 \\
\hline
\end{tabular}

Table 11: Sources of $\mathrm{cms}$ produced by interspecific hybridization

\begin{tabular}{lccccc}
\hline Origin & $\begin{array}{c}\text { Obtained } \\
\text { in generation }\end{array}$ & $\begin{array}{c}\text { Year of } \\
\text { observation }\end{array}$ & $\begin{array}{c}\text { Year of } \\
\text { report }\end{array}$ & $\begin{array}{c}\text { DAl } \\
\text { code }\end{array}$ & $\begin{array}{c}\text { F.A.O. } \\
\text { code }\end{array}$ \\
\hline H. annuus E - 067 & $\mathrm{F}_{1}$ & 1985 & 1992 & AN-67 & ANN-10 \\
H. annuus E - 058 & $\mathrm{F}_{6}$ & 1988 & 1994 & AN-58 & ANN-11 \\
H. annuus E - 002 & $\mathrm{F}_{5}$ & 1991 & 1991 & AN-2-1 & ANN-12 \\
H. annuus E - 002 & $\mathrm{F}_{6}$ & 1992 & 1992 & AN-2-2 & ANN-13 \\
H. argophyllus E - 006 & $\mathrm{F}_{1}$ & 1984 & 1990 & ARG-1 & ARG-1 \\
H. argophyllus E - 006 & $\mathrm{BC}_{1}$ & 1987 & 1990 & ARG-3 & ARG-3 \\
H. argophyllus E - 007 & $\mathrm{F}_{1}$ & 1985 & 1992 & ARG-2 & ARG-2 \\
H. debilis E - 010 & $\mathrm{F}_{2}$ & 1990 & 1994 & DV-10 & DEB-1 \\
H. petiolaris E - 034 & $\mathrm{BC}_{1} \mathrm{~F}_{6}$ & 1991 & 1991 & Pet-34 & PET-4 \\
H. praecox E - 027 & $\mathrm{F}_{2}$ & 1990 & 1990 & PHIR-27 & PRH-1 \\
H. praecox E - 029 & $\mathrm{F}_{4}$ & 1989 & 1989 & PRUN-29 & PRR-1 \\
H. rigidus M - 028 & $\mathrm{BC}_{1} \mathrm{~F}_{2}$ & 1991 & 1991 & Rig-28 & RIG-2 \\
H. strumosus M - 056 & $\mathrm{BC}_{1} \mathrm{~F}_{5}$ & 1991 & 1996 & Strum-56 & STR-1 \\
H. argophyllus E - 007 & $\mathrm{BC}_{1} \mathrm{~F}_{7}$ & 1995 & 1998 & ARG-4 & ARG-4 \\
H. argophyllus E - 006 & $\mathrm{new} \mathrm{BC}_{1}$ & 1997 & 2000 & ARG-3-M-1 & ARG3M1 \\
\hline
\end{tabular}


HELIA, 36, Nr. 58, p.p. 1-18, (2013)

Table 12: Characterization of $\mathrm{R}$ lines, produced from interspecific and intergeneric hybridization harvested in 2010

\begin{tabular}{|c|c|c|c|c|c|c|}
\hline \multirow[t]{2}{*}{ No } & \multirow[t]{2}{*}{ Origin } & $\begin{array}{c}\text { Plant } \\
\text { height }\end{array}$ & $\begin{array}{c}\text { Head } \\
\text { diameter }\end{array}$ & $\begin{array}{l}\text { Vegetation } \\
\text { period }\end{array}$ & $\begin{array}{l}\text { Seed oil } \\
\text { content }\end{array}$ & \multirow[t]{2}{*}{ Generation } \\
\hline & & $\mathrm{cm}$ & $\mathrm{cm}$ & days & $\%$ & \\
\hline PR-1/8 & c.s. $\times$ H. pauciflorus M-028 & 110 & 13 & 100 & 48.48 & $19^{*}$ \\
\hline PR-13/8 & c.s. $\times$ H. pumilus $\mathrm{M}-172$ & 105 & 14 & 98 & 58.28 & $17^{*}$ \\
\hline PR-41/8 & c.s. $\times$ H. divaricatus M-044 & 130 & 16 & 102 & 47.03 & $18^{*}$ \\
\hline PR-47/8 & c.s. $\times$ H. bolanderi E-009 & 140 & 15 & 103 & 50.44 & $15^{*}$ \\
\hline PR-51/8 & c.s. $\times$ Carduus acanthoides & 120 & 14 & 100 & 52.96 & $16^{*}$ \\
\hline PR-57/8 & c.s. $\times$ Inula sp. $/ \times$ Tith. & 140 & 15 & 102 & 50.35 & $17^{*}$ \\
\hline Sc-17 & c.s. $\times$ Grindelia speciosa & 105 & 16 & 100 & 49.11 & $15^{*}$ \\
\hline Sc-23 & c.s. $\times$ Telekia speciosa & 90 & 13 & 95 & 51.39 & $17^{*}$ \\
\hline Sc-58 & c.s. $\times$ Tith. $/ \times$ Verbesina sp. & 110 & 17 & 104 & 48.12 & $15^{*}$ \\
\hline C 23/1 & c.s. $\times$ H. debilis E-011 & 105 & 17 & 103 & 49.16 & $17^{*}$ \\
\hline C 55 & c.s. $\times$ H. debilis E-011 & 120 & 16 & 105 & 52.71 & $15^{*}$ \\
\hline C 56 & c.s. $\times$ H. hirsutus M-029 & 115 & 17 & 105 & 52.38 & $15^{\star}$ \\
\hline
\end{tabular}

*branched forms

\section{New sunflower forms with normal cytoplasm (B lines)}

New B lines were created from forms only obtained by interspecific hybridization. The total number of developed "B" lines up to 2010 was 289 . The stem height varies from 45 to $180 \mathrm{~cm}$, and the vegetation period varies from 86 to 125 days. Thousand seed weight varies from 30 to $125 \mathrm{~g}$, and the seed oil content varies from 40 to $54 \%$ (Table 13). Some B lines have resistance to Phomopsis and others to downy mildew and broomrape. Such lines are 6066B, 6101B, 6134B, 6149B, 6488B, and 6748B. Sterile analogues were also developed for all B lines in $\mathrm{cms}$ PET 1. Sterile analogues for the rest of the $\mathrm{cms}$ sources were used to create four lines with the aim to test theses lines in experiments evaluating cytoplasmic effect on some agricultural characters for the development of new hybrids.

Table 13: Characteristics of B lines produced from interspecific hybridization

\begin{tabular}{llcccc}
\hline \multirow{2}{*}{ No. } & Origin & $\begin{array}{c}\text { Plant } \\
\text { height }\end{array}$ & $\begin{array}{c}\text { Head } \\
\text { diameter }\end{array}$ & $\begin{array}{c}\text { Seed oil } \\
\text { content }\end{array}$ & $\begin{array}{c}\text { Vegetation } \\
\text { period }\end{array}$ \\
\cline { 3 - 6 } & $\mathrm{cm}$ & $\mathrm{cm}$ & $\%$ & days \\
\hline 6101 & H. decapetalus - M-043 & 125 & 18 & 47.35 & 106 \\
6134 & H. debilis - E-011 & 100 & 22 & 48.08 & 107 \\
6159 & H. pauciflorus - M-028 & 155 & 15 & 48.79 & 105 \\
6170 & H. strumosus - M-056 & 110 & 12 & 47.82 & 110 \\
6202 & H. hirsutus - M-029 & 105 & 12 & 45.25 & 105 \\
6215 & H. salicifolius - M-045 & 180 & 18 & 51.15 & 107 \\
6275 & H. argophyllus - E-007 & 140 & 23 & 49.96 & 105 \\
6149 & H. eggertii - M-001 & 140 & 24 & 48.91 & 103 \\
\hline
\end{tabular}




\section{New sunflower hybrid combinations}

During the developing and investigation of new sunflower hybrids, two groups were formed. The first group included crosses between old, confirmed Bulgarian A / $\mathrm{B} /$ lines with $\mathrm{R}$ lines obtained from interspecific and intergeneric hybrids, and the second group included crosses between new A/B/ lines, obtained by using mutagenesis and $\mathrm{R}$ lines obtained by wide hybridization. There were a small number of hybrid combinations created from $\mathrm{B}$ lines obtained from the wide hybridization and $\mathrm{R}$ lines obtained by the same method. Each year 350 to 370 hybrid combinations are produced for testing. Three-fourth of tested hybrids were oil seed types and the rest were developed as large-seeded hybrids, and hybrids with colored seeds for birds.

\section{New sunflower hybrid varieties in registration}

New sunflower hybrids were created which increased seed yield and seed oil content per unit area higher than the standard hybrid check. Five of these hybrids, Musala, Mura, Maritsa, Mesta and Magura were registered with the State Variety Commission at the end of 2004. At the beginning of 2008, the first large-seeded hybrid Madan was registered. The paternal source of hybrids Musala, Mura, Maritsa, Mesta and Magura and the maternal source of hybrid Madan were created from materials obtained by interspecific hybridization. The paternal source of hybrid Madan was obtained by intergeneric hybridization.

\section{CONCLUSION}

The results of this investigation showed that successful interspecific and intergeneric hybridization was achieved and the transfer of new genetic material into cultivated sunflower was possible. Hybrids with valuable characters were obtained. Lines developed from these crosses can be used in developing high quality sunflower hybrids. The new sources of $\mathrm{cms}$ and $R f$ genes increases the genetic diversity of current single cms - $R f$ system widely used in heterotic breeding. The results obtained from this investigation confirm the valuable contribution interspecific and intergeneric hybridization can make to a sunflower breeding program.

\section{REFERENCES}

Alonso, C., 1996. New highly virulent sunflower broomrape (Orobanche cumana Wallr.) phenotypes in Spain. Advances in parasitic plant research. Proc. $6^{\text {th }}$ Int. Parasitic Weed Simposium, April 16-18, 1996, Cordoba, Spain.

Anashchenko, A.B., 1974. Citoplasmaticheskie form mujskoi sterilnosti u podsolnechnika. Dokl. VASHNIL 4: 11-12.

Bachvarova, R., 2004. Proutcvanija varhu sinjata kitka (Orobanche spp.) pri slancogled i tjutjin. Dissertation, Sofia.

Christov, M., 1990a. Study on wild species Helianthus with aim of using in sunflower breeding. PhD Dissertation, Bulgarian Academy of Agriculture, Sofia. 
Christov, M., 1990b. A new source of cytoplasmic male sterility in sunflower originated from H. argophyllus. Helia 13: 55-61.

Christov, M., 1996a. Characterization of wild Helianthus species as sources of new features for sunflower breeding. Proc. Int. Compositae Conf., Kew, 1994, Caligari, P.D.S. and Hind, D.J.N. (Eds.). Compositae: Biology and Utilization, Royal Botanic Gardens, Kew, 2: 547 570.

Christov, M., 1996b. Hybridization of cultivated sunflower and wild Helianthus species. Proc. Int. Compositae Conf., Kew, 1994, Caligari, P.D.S. and Hind, D.J.N. (Eds.). Compositae: Biology and Utilization, Royal Botanic Gardens, Kew, 2: 603-615.

Christov, M., 1999. Production of new cms sources in sunflower. Helia 22(31):1-12.

Christov, M., 2002. Resultati ot prilaganeto na otdalecena hybridizatija i eksperimentalen mutagenez pri podobritelnata rabota sas slancogleda. Iubileina nautcna sesija - 50 godini Dobruddzanski zemedelski institut, I: 315-335.

Christov, M., 2008. Helianthus species in breeding on sunflower. Proc. $17^{\text {th }}$ Int. Sunfl. Conf., Cordoba, Spain, Int. Sunfl. Assoc., Paris, France, 2: 709-714.

Christov, M. and Petrov, P., 1988. New source of $R f$ genes for $c m s$ on the basis of $H$. petiolaris. Genetics and Selection 21(5).

Christov, M. and Panayotov, L., 1991. Hybrids between the genera Helianthus and Tithonia and their study. Helia 14: 27-34.

Christov, M. and Vassilevska-Ivanova, R.D., 1999. Intergeneric hybrids in Compositae (Asteraceae). I. Hybridization between cultivated sunflower $H$. annuus L. and Compositae Genera. Helia 22(31): 13-22.

Christov, M., Shindrova, P. and Encheva, V., 1992. Phytopathological characterization of wild species in the genus Helianthus in view of their use in breeding for resistance. Genet. Breed. 25: 45-51.

Christov, M., Vassileva, R., Tsujimoto, H. and Panayotov, I., 1994. Intergeneric hybridization between sunflower and some species of genera from Compositae. Int. Compositae Conf., Royal Botanic Gardens, Kew, 26.07-05.08.

Christov, M., Shindrova, P. and Entcheva, V., 1996. Transfer of new characters from wild Helianthus species to cultivated sunflower. Genet. a Slecht. 32(4): 275-286.

Christov, M., Kiryakov, I., Shindrova, P., Encheva, V. and Christova M., 2004. Evaluation of new interspecific and intergeneric sunflower hybrids for resistance to Sclerotinia sclerotiorum. Proc. $16^{\text {th }}$ Int. Sunfl. Conf., Fargo, North Dakota, USA, Int. Sunfl. Assoc., Paris, France, II: 693-698.

Christov, M., Hristova-Cherbadzi, M., Nikolova, V., Ivanova, I. and P. Shindrova. 2009. Medzdurodova hybridizatija pri slancogleda - rezultati i problemi. Sbornik dokladi ot medzdunarodna naucna konferencija. In: Dobri praktiki za ustoitcivost zemedelsko proizvodstvo. Lesotehnitceski universitet, Sofia, pp. 167-184.

Cvetkova, F., 1976. Njakoi rezultati ot izpolzvane na medzduvidovata hybridizatija pri selekcijata na slancogleda. Genetika i selekcija 9(3): 194-201.

Encheva, V. and Kiryakov, I., 2002. A method for evalution of sunflower resistance to Diaporthe/ Phomopsis helianthi Munt.-Cvet. Bulgarian Journal of Agricultural Science 8: 219-222.

Enns, H., Dorrell, D.G., Hoes, J.A. and Chubb, W.O., 1970. Sunflower research. Proc. $4^{\text {th }}$ Int. Sunfl. Conf., Memphis, Tennessee. Int. Sunfl. Assoc., Paris, France. Progress report, pp. 162-167.

Fernandez-Martinez, J. and Ruso, J., 1997. Evaluation of wild Helianthus species. FAO Progress Report 1995-1996, Giessen, Germany, pp. 43-46.

Fernandez-Martinez, J.M., Malero-Vara, J., Muñoz-Ruiz, J., Ruso, J. and Domingez, J., 2000. Selection of wild and cultivated sunflower for resistance to a new broomrape race that overcomes resistance of the $\mathrm{Or}_{5}$ gene. Crop Science 40(2): 550-555.

Fick, G.N., Zimmer, D.E., Dominguez-Gimenez, J. and Rehder, D.A., 1974. Fertility restoration and variability for plant and seed characteristics in wild sunflower. Proc. $4^{\text {th }}$ Int. Sunfl. Conf., Bucharest, Int. Sunfl. Assoc., Paris, France, pp. 333-338.

Georgieva-Todorova, J., 1971. Further study of the form obtained after crossing Helianthus annuus L. with Onopordum acanthium L. Genetics and Breeding 4(6): 396-408.

Georgieva-Todorova, J., 1976. Megdurodovi otnoshenia v roda Helianthus L., Sofia, BAS.

Gulya, T., Rashid, K.Y. and Maširević, S., 1997. Sunflower Diseases. In: Schneiter, A.A. (Ed.), Sunflower Technology and Production pp. 263-379.

Heiser, C.B., 1982. Registration of Indiana - $1 \mathrm{cms}$ sunflower germplasm. Crop Science 22(5): 1089. 
Heiser, C.B.Jr., Smith, D.M., Clevinger, S.B. and Martin, W.C.Jr., 1969. The North American Sunflower (Helianthus). Mem. Torrey Botanical Club 22(3): 3.

Hoes, J.A., Putt, E.D. and Enns, H., 1973. Resistance to Verticilium wild in collections of wild Helianthus in North America. Phytopathology 63: 1517-1520.

Hristova-Cherbadzhi, M., 2007. Study of new sunflower forms by remote hybridization. Ph.D. Dissertation, Sofia.

Hristova-Cherbadzhi, M., 2012. Study of new forms of sunflower received by distent hybridization. Breeding and genetics of cultivated sunflower - methods, new lines, new crosses, new cms source. Lambert Academic Publishing, ISBN 978-3-659-13617-7.

Iliescu, H., 1955. Proposed methodologies for inoculation of sunflower with different pathogens and for disease assessment. Bucharest.

Iurras, M. and Voinescu, A., 1984. Utilizarea speciei Helianthus argophyllus Torrey \& Gray, pentru obtinerea unor forme xerofite de floarea-soarelui. In: Probleme de genetica teoretica si aplicata, Fundulea 16(2): 123-130.

Ivanov, P., Christov, M., Ivanova, I. and Nikolova, V., 1996. Study of seed oil and protein quality of some Bidens tripartita accessions. Helia 19(25): 79-85.

Jan, C.C. and Chandler, J.M., 1985. Transfer of powdery mildew resistance from Helianthus debilis Nutt. to cultivated sunflower. Crop Science 25(4).

Kinman, M.L., 1970. New development in the USDA and state experiment station sunflower breeding program. Proc. $4^{\text {th }}$ Int. Sunfl. Conf., Memphis, USA, Int. Sunfl. Assoc., Paris, France, pp. 181-183.

Leclercq, P., 1969. Une sterile male cytoplasmique chez le tournesol. Ann. Amelior Plant 19: 99-106.

Leclercq, P., 1971. La sterilite male cytoplasmique du tournesol. I. Premieres etudes sur la restauration de la fertilite. Ann. Amelior Plant 21: 45-54.

Leclercq, P., Gauderon, Y. and Dauge, M., 1970. Selection pour la resistance au mildiou du tournesol apartir d'hybrides topinambour $\times$ tournesol. Ann. Amelior Plant 20(3): 363373.

Morized, J., Cruizilat, P., Chatenoud, J., Picot, P. and Leclercq, P., 1984. Improvement of drought resistance in sunflower by interspecific crossing with a wild species Helianthus argophyllus. Methodology and $1^{\text {st }}$ results. Agronomie 4: 577-585.

Morozov, V.K., 1947. Selekcia podsolnechnika v SSSR. Pistepromizdat, Moskva, 272.

Pacureanu-Joita, M., Vranceanu, A.V., Soare, G., Marinscu, A. and Sandu, I., 1998. The evaluation of the parasite-host interaction system (Helianthus annuus L.) - (Orobanche cumana Wallr.) in Romania. Proc. $2^{\text {nd }}$ Balkan Symposium on Field Crops. 16-20 June, 1998. Novi Sad, Yugoslavia, Int. Sunfl. Assoc., Paris, France, pp. 153-155.

Panchenko, A., 1954. Gibridi podsolnechnika s topinamburom. V sb.: Kratkoi otchet $\mathrm{s}$ nauchno-issledovatelskoi rabote VNIIMK za 1953. Krasnodar, Sovetskaia Kuban.

Panchenko, A., 1965. Rapid method of evaluation of sunflower for resistance to mildew. Selectia i semeproizvodstvo 2: 52-54.

Panchenko, A., 1975. Rannaja diagnostika zarazihoustoitcivosti pri selekcii i ulucshajutshem semenovodstve podsolnetcnika. Vestnik selskohozjaistvennoi nauki 2: 107-115.

Pustovoit, V., 1960. Medzvidovie i rdzavtcinoustoitcivie gibridi podsolnetcnika. In: Otdaletcennaja gibridizacija rastenii. Moskva, 376-378.

Pustovoit, G., 1963. Selekcija podsolnetcnika na gruppovoi immunitet metodom medzvidovoi gibridizacii. Masl. i efiromaslitcnoi kulturii, Moskva, 75-92.

Pustovoit, G., 1975. Selekcija podsolnetcnika na gruppovoi immunitet metodom medzvidovoi gibridizacii. In: Podsolnetcnik. izd. "Kolos", Moskva, 164-209.

Pustovoit, G.V., Krasnokutskaya, O.N., Platovskii, U.P. and Slyussar, EL. 1976. Phytopathological methods of sunflower evaluation in breeding for resistance to basic diseases. Bul. Sc. Techn. Infor. Of Oil Crops. vol. 1. Krasnodar.

Putt, E.D. and Sackston, W.E., 1957. Studies on sunflower rust. I. Some sources of rust resistance. Can. J. Plant Science 37: 43-54.

Putt, E.D. and Sackston, W.E., 1963. Studies on sunflower rust. IV. Two genes $R_{1}$ and $R_{2}$ for resistance in the host. Can. J. Plant Science 43: 490-496.

Rushkovskij, C.B., 1957. Metodi issledovanii pri selekcii maslitcnih pastenii na soderdzanie masla i ego katcestvo. M. Pitshepromizdat.

Satziperov, F., 1916. Opit skretshivanija dvuh form podsolnetcnika Helianthus annuus $\mathrm{x}$ Helianthus argophyllus. Tr. prikl. bot., gen. i selek. 9: 207-244. 
Saliman, M., Yang, S.M. and Wilson, L., 1982. Reaction of Helianthus species to Erysiphe cichoracearum. Plant Dis. 66: 572-573.

Schilling, E.E. and Heiser, C.B., 1981. Infrageneric classification of Helianthus (Compositae). Taxon 30: 393-403.

Serieys, H., 1986. Characterisation of some new cytoplasmic androsterilities sources from Helianthus genus. F.A.O. Meeting, July 21-25, Sindos, Greece.

Serieys, H. and Vincourt, P., 1987. Characterization of some new cytoplasmic male sterility sources from Helianthus genus. Helia 10: 9-13.

Shindrova, P., 2006a. Downy mildew (Plasmopara halstedii Farl. Berlese et de Tony) distribution and race composition during 2004-2005. $70^{\text {th }}$ Anniversary of Plant Protection Institute and Annual Balkan Week of Plant Health - Plant Protection Institute, May 28-31, 2006, Kostinbrod, Bulgaria, Book of Abstracts, p. 22.

Shindrova, P., 2006b. Broomrape (Orobanche cumana Wallr.) in Bulgaria - Distribution and race composition. Helia 29.

Škorić, D., 1985. Sunflower breeding for resistans to Diaporthe (Phomopsis helianthi). Helia 8: 21-23.

Škorić, D., Ćuk, L., Mihaljčević, M. and Marinković, R., 1978. New sources of fertility restoration ( $R f$ genes) and downy mildew resistance ( $P l$ genes) in Sunflowers. Proc. $8^{\text {th }}$ Int. Sunfl. Conf., Minneapolis, Int. Sunfl. Assoc., Paris, France, pp. 423-426.

Škorić, D., Atlagić, J., Marinković, R., Vasiljević, L., Mihaljčević, M. and Maširević, S., 1987. In: Škorić, D. (Ed.), Progress report - 1984-1986, FAO Subnetwork, Szeged.

Stojanova, J. and Ivanov, P., 1968. Proutcvanija varhu podgotovkata na semenata ot slantcogleda za laboratorno opredeljane na maslenostta im. Rastenievadni nauki 5(4): 49-57.

Tourvieille, D., Vear, F. and Pelletier, C., 1988. Use of two mycelium tests in breeding sunflower resistance to Phomopsis. Proc. $12^{\text {th }}$ Int. Sunfl. Conf., II: 110-114.

Vranceanu, A.V., and Stoenescu, F., 1971. Pollen restorer gene from cultivated sunflower (Helianthus annuus L.). Euphytica 20(4): 536-541.

Vranceanu, A.V. and Stoenescu, F., 1976. Breeding for pollen fertility restoration in sunflower. Proc. $7^{\text {th }}$ Int. Sunfl. Conf., Krasnodar. Int. Sunfl. Assoc., Paris, France.

Vranceanu, A.V. and Stoenescu. F., 1978. Genes for pollen fertility restoration in sunflower. Euphytica 27(2): 617-627.

Vranceanu, A.V., Iuoras, M. and Stoenescu, F., 1986. A contribution to the diversification of cytoplasmic male sterility sources in sunflower. Helia 9: 21-25.

Whelan, E.D.P., 1980. A new source of cytoplasmic male sterility in sunflower. Euphytica 29: 346.

Whelan, E.D.P., 1981. Cytoplasmic male sterility in Helianthus giganteus L. x H. annuus L. interspesific hybrids. Crop Science 21(6): 855-858.

Zimmer, D.E. and Fick, G.N., 1974. Some diseases of sunflower in the United States - their occurrence, biology and control. Proc. $6^{\text {th }}$ Int. Sunfl. Conf., Bucharest, Int. Sunfl. Assoc., Paris, France, pp. 673-680. 